\title{
On embracing the concept of becoming environmental problem solvers: the trainee perspective on key elements of success, essential skills, and mindset
}

\author{
A.P. Gale, J.O. Chapman, D.E. White, P. Ahluwalia, A.K.J. Williamson, K.R. Peacock, R. Akagbosu, \\ T.M. Lepine, I. Arizor, L.A. Bone, J. Brown, A.M. Fahrngruber, A. Goldberg-Flood, S. Kovirineni, \\ S.J. Lamb-Laurin, N. Zia, S. Innocent, W. Lee, G. Moran, B. Nwasoria, N.A. Ouellette, R. Pendlebury, \\ A. Prue, J. Sokolowski, P. Namutosi, T. Tesfay, M.C.M. Oliver, E.A. Nyboer, and S.J. Cooke
}

\begin{abstract}
Life in the Anthropocene is characterized by many environmental problems, and unfortunately, more continue to emerge. Although much effort is focused on identifying problems, this does not necessarily translate to solutions. This situation extends to the training environment, where students are often adept at understanding and dissecting problems but are rarely explicitly equipped with the skills and mindset to solve them. Herein, a group of undergraduate students and their instructors consider the concept of becoming environmental problem solvers. We first identified themes associated with historical and contemporary environmental successes that emerged from our reading, or more specifically, we identify the elements that underlie environmental success stories. The key elements of success involved setting clear objectives, identifying the scale of the problem, learning from failure, and consulting diverse knowledge sources. Next, we reflected on the skills and mindset that would best serve environmental problem solvers and enable future successes. Essential skills include innovative and critical thinking, ability to engage in collaborative teamwork, capacity to work across boundaries, and resilience. In terms of mindset, key attributes include the need for courage, enthusiasm and commitment, optimism, open mindedness, tenacity, and adaptability. We conclude with a brief discussion of ideas for revising training and curriculum to ensure that students are equipped with the aforementioned skills and mindset. The ideas shared here should contribute to ensuring that the next generation of learners have the ability to develop solutions that will work for the benefit of the environment, biodiversity, and humanity. Solving environmental problems will increasingly fall to the next generation, so it is time to ensure that they are prepared for that task.
\end{abstract}

Key words: Anthropocene, environmental problems, problem solving, solutions, trainees.

Résumé : La vie dans l'Anthropocène est caractérisée par de nombreux problèmes environnementaux et, malheureusement, d'autres continuent d'apparaître. Bien que de nombreux efforts soient consacrés à l'identification des problèmes, cela ne se traduit pas nécessairement en solutions. Cela se répercute sur l'environnement de formation où les étudiants sont souvent habiles à comprendre et disséquer des problèmes, mais sont rarement explicitement équipés des compétences et de l'état d'esprit nécessaires pour les résoudre. Ici, un groupe d'étudiants de premier cycle et leurs enseignants réfléchissent à l'adoption du concept de devenir des personnes aptes à résoudre des problèmes environnementaux. Les auteurs identifient d'abord les thèmes associés aux réussites environnementales historiques et contemporaines qui sont ressortis de leurs lectures - ou plus précisément, ils identifient les éléments de la recette qui sous-tendent les réussites environnementales. Les éléments clés du succès impliquaient de fixer des objectifs clairs, d'identifier l'ampleur du problème, de tirer les leçons des échecs et de consulter diverses sources de connaissances. Ensuite, ils réfléchissent aux compétences et à l'état d'esprit qui pourraient le mieux servir les personnes chargées de résoudre les problèmes environnementaux et permettre de futurs succès. Les compétences essentielles comprennent la pensée innovante et critique, la capacité à s'engager dans un travail d'équipe collaboratif, la capacité à travailler au-delà des frontières et la résilience. En matière d'état d'esprit, les attributs clés comprennent le besoin de courage, d'enthousiasme et d'engagement, l'optimisme, l'ouverture d'esprit, la ténacité et l'adaptabilité. Ils concluent par une brève discussion des idées de révision de la formation et des programmes d'études afin de garantir que les étudiants soient dotés des compétences et de l'état d'esprit susmentionnés. Les idées partagées ici devraient contribuer à faire en sorte que la prochaine génération d'apprenants ait la capacité de développer des

Received 17 April 2021. Accepted 17 June 2021.

A.P. Gale, ${ }^{*}$ J.O. Chapman,* D.E. White,* P. Ahluwalia,* A.K.J. Williamson,* K.R. Peacock,,* R. Akagbosu,* T.M. Lepine,* I. Arizor,* L.A. Bone,*

J. Brown, * A.M. Fahrngruber, * A. Goldberg-Flood, * S. Kovirineni,* S.J. Lamb-Laurin, ${ }^{*}$ N. Zia, ${ }^{*}$ S. Innocent, * W. Lee, * G. Moran,* B. Nwasoria,* N.A. Ouellette, ${ }^{*}$ R. Pendlebury, ${ }^{*}$ A. Prue, ${ }^{*}$ J. Sokolowski, ${ }^{*}$ P. Namutosi,* T. Tesfay,, M.C.M. Oliver, ${ }^{*}$ E.A. Nyboer, ${ }^{*}$ and S.J. Cooke. ${ }^{*}{ }^{*}$ Institute of Environmental and Interdisciplinary Science, Carleton University, 1125 Colonel By Drive, Ottawa, ON K1S 5B6, Canada.

Corresponding author: S.J. Cooke (email: Steven_Cooke@carleton.ca).

*All of the authors contributed equally to this paper.

${ }^{\dagger}$ Steven J. Cooke served as an Advisory Board Member at the time of manuscript review and acceptance; peer review and editorial decisions regarding this manuscript were handled by Kathleen Rühland.

(c) 2021 The Author(s). This work is licensed under a Creative Commons Attribution 4.0 International License (CC BY 4.0), which permits unrestricted use, distribution, and reproduction in any medium, provided the original author(s) and source are credited. 
solutions qui fonctionneront dans l'intérêt de l'environnement, de la biodiversité et de l'humanité. La résolution des problèmes environnementaux incombera de plus en plus à la prochaine génération, il est donc temps de s'assurer qu'elle est préparée à cette tâche. [Traduit par la Rédaction]

Mots-clés : Anthropocène, problèmes environnementaux, résolution de problèmes, solutions, stagiaires.

\section{Introduction}

Humans are a powerful driver of environmental change (Vitousek et al. 1997). It is now well accepted that we have entered a new era called the Anthropocene (Crutzen 2006) that is characterized by the manifold effects of humans on the environment and biodiversity (Lewis and Maslin 2015). Human activities and the environment are entirely inter-related, such that the feed-back from environmental impacts often intersects with or exacerbates societal issues ranging from social justice to food security, as exemplified by the UN Sustainable Development Goals (Reid et al. 2017). Accepting that we are in the Anthropocene and faced with numerous environmental problems requires a critical shift in focus toward finding solutions (Steffen et al. 2011). Solving the problems that impede achieving the UN Sustainable Development goals and a "good" Anthropocene (Dalby 2016) would be transformational in achieving a more just, humane, and sustainable future (Stevens and Kanie 2016; Bebbington and Unerman 2018; Elmqvist et al. 2019).

Environmental problems are often "wicked problems" (Blaint et al. 2011) that transcend scales (institutional, jurisdictional, spatial, and temporal) and comprise high levels of inherent uncertainty (see Miller 1999 for a historical and philosophical perspective). Moreover, economic, institutional, and policy forces intersect with human behaviours and values in complex ways that make identifying solutions challenging (Gardner and Stern 1996; Kinzig et al. 2013). It therefore is not entirely surprising that efforts have largely focused on problem identification as opposed to finding concrete, actionable solutions (Johnston 1989; Trudgill 1990; Ewel 2001; Costanza and Jorgensen 2002). That is not to imply that there have not been successes (or partial successes) in solving environmental problems today or in the past (e.g., Rachel Carson and the regulatory ban of DDT enabling the recovery of raptor populations; other examples reviewed in Miller 1999). Those successes range from global initiatives and policy instruments to local initiatives driven by individuals and communities (see Bennett et al. 2016; Pereira et al. 2019). Yet, many of those successes are incremental and fail to address the root cause(s) of environmental degradation that are often embedded in issues related to the economy, social justice, global conflicts, governance, and so on: in other words, they are bandaid solutions (e.g., Krumholz et al. 2010). In fact, because environmental problems are rarely solved in their entirety, some in the environmental community have adopted the terminology of "bright spots" and "dark spots" to describe the successes and failures of past conservation action (see Bennett et al. 2016). We recognize that most environmental problems are multifaceted so incremental progress towards solutions is valuable and inevitable, yet we are in desperate need for a more transformational and holistic approach to environmental problem solving (Washington 2015) - so called radical change (Tukker et al. 2017). Although there are some signs for hope, there has yet to be a collective transition from identifying environmental problems to developing meaningful solutions.

Although the environmental problems of today have a historical basis, current and future generations of environmental problem solvers are tasked with finding tangible solutions (Lim et al. 2017; Jeanson et al. 2020). It therefore follows that early career environmental trainees and professionals must play a central role in identifying pathways to success (Kelly et al. 2019; Jeanson et al. 2020). To do so, they need to be equipped with the skills and mindset to embrace the bold task of becoming environmental problem solvers (Wei et al. 2020). In most contemporary university environmental programs and training environments, students become adept at understanding and dissecting problems (e.g., issue identification, critical thinking, applying the scientific method; Proulx 2004; Hofreiter et al. 2007) but rarely are they explicitly equipped with the skills and mindset to solve them (Cohen 2007). We represent the members of a 4th year undergraduate class titled "Environmental Solutions" held at Carleton University (Ottawa, Canada), and have devoted a semester to embracing the concept of becoming environmental problem solvers. Here we share our perspectives on this topic in the hopes that it will help to inspire other trainees to join us. We also hope that the ideas shared here will resonate with mentors, instructors, practitioners, and leaders in environmental and educational institutions so that they can, through appropriate training, enable such change to occur. First, we identify themes associated with historical and contemporary environmental successes that emerged from our reading, or more specifically, we identify the elements that underlie environmental success stories. Next, we reflect on the skills and mindsets that would best serve environmental problem solvers. Finally, we conclude with a brief discussion of ideas for revising undergraduate training and curricula to ensure that students are equipped with the aforementioned skills and mindsets. This is a perspective article (rather than a review), so the ideas shared represent our collective viewpoints based on our lived experiences and learning in this space. Where possible we anchor and support our ideas in the literature using selected references and examples.

\section{Key elements of success}

Reflections on existing success stories can be used to identify the key elements of such successes. Here we share some of those key elements of success.

\section{Setting clear objectives}

One of the most critical aspects to solving problems is properly defining what is required to succeed. Many environmental projects are deemed failures after going overbudget, misplacing efforts, or missing their target due to the lack of a clear objective and associated (measurable) targets (e.g., Zedler 2007; Ford et al. 2021). A critical first step for problem solving should be identifying an achievable target for a project and carefully planning what is required to achieve it (Bardwell 1994). By doing this, a project can be mapped out from start to finish instead of being hastily modified to fit new and changing objectives and terms, notwithstanding the need to include an adaptive aspect to project design and implementation. Setting a clear goal effectively brackets the problem such that efforts do not deviate into tangents, but instead progress towards the specified goal (Klimoski and Karol 1976). This also provides room to divide up the aspects of a project in a way that maximizes the diverse talents and skillsets of your team such that they are directed to where they are most needed (Cooke et al. 2020a). By establishing clear goals, one can evaluate all the circumstances hindering progress (Toll 1999). Smaller, stepwise goals should be considered by problem solvers as an alternative method when larger steps are restricted by financial limitations, network gaps, and informational constraints. Smaller steps also serve as indicators of progress towards the final goal which allows for refinement of project goals (Reyers et al. 2017).

\section{Understanding the problem}

Another key early step to problem solving is understanding the problem and considering the cascading effects of a solution; if 
you change something here, will it have unintended consequences and create problems elsewhere? For example, if you achieve "zero waste" in your city by shipping garbage to another country, you may have solved your specific garbage problem but have created a larger (potentially insurmountable) issue in other locations (Robinson 2009). Another key task is to understand the spatial, temporal, and institutional scale of a problem (Raudsepp-Hearne and Peterson 2016). This is necessary to identify the scope and thus the arena in which problem solving needs to occur. The use of theory of change models (Hayes 2018), conceptual models (Moody 2005), or pathway of effect diagrams (Sloman 2005) can help to visualize and identify the scale and reach of the problem and ensure that efforts focus on elements that have the potential to enable change.

\section{Learning from failure}

Given the scope and complexity of environmental issues, it is not surprising that solutions often fail to address a problem, or even result in new issues (Young and Stokke 2020). While failure may occur due to negligence or human error, the numerous feedback systems and dynamic nature of environmental problems means that one static all-encompassing solution is rarely possible. In addition, the ever-shifting state of the environment, novel feedback loops with human activity, and current knowledge gaps mean that many "solutions" inevitably result in failure. It is critical, however, that we learn from past failures and adapt future environmental solutions to be more effective at combating problems (Vallero 2006). It is also important to share failures so that others have the chance to reflect on the conditions, factors, and lessons that emerge from those experiences (Tawfik and Jonassen 2013). Unfortunately, most failures are not shared (e.g., in the peer reviewed literature) making such learning difficult (Evans and Cvitanovic 2018). Cooke (2019) reflected on a number of applied environmental projects focused on generating solutions and discussed frustrations and failures - something that should be encouraged more broadly. Accepting failure as part of the process allows problem solving to be progressive in nature, with each solution being more informed than the last (Boivin and Crowther 2021).

\section{Combining technological and behavioural concepts to achieve solutions}

For decades, researchers and other innovators have attempted to "engineer" our way out of environmental crises, yet there is strong evidence that technological solutions will only get us so far (Huesemann 2001; Van den Bergh 2013). Similarly, much effort has been devoted to identifying solutions that involve behavioural science approaches (e.g., nudges, cognitive dissonance, and rewards) to encourage pro-environmental behaviours and policies, but the evidence supporting such efforts is mixed (Osbaldiston and Schott 2012). By combining technological and behavioural solutions, it should be possible to address the inherent deficiencies of each individual approach. For example, consider a scenario where a new technology is developed that addresses an environmental problem but it is not embraced by the public. Combining technological and behaviour concepts should lead to more rapid adoption of solutions that work. A good example involves single use plastics such as drinking straws where the combination of innovation in straw design and use of alternative materials combined with extensive outreach efforts focused on changing consume behaviour have collectively helped to make meaningful advances on solving the problem of single-use plastic marine pollution (Schnurr et al. 2018).

\section{Consider diverse forms of knowledge}

It is not uncommon for there to be an abundance of sciencebased knowledge to apply to environmental problems (Tsuji and Ho 2002), yet other forms of knowledge and ways of knowing are often excluded (Meppem and Bourke 1999). Weaving multiple types of knowledge such as Indigenous knowledge and stakeholder knowledge with Western science-based knowledge allows for a more holistic understanding of the complex interlinkages between human action and the environment (Alexander et al. 2019). For example, Reid et al. (2021) have advocated for a "two-eyed seeing" approach to addressing fisheries problems. Two-eyed seeing involves learning to see from one eye with the strengths of Indigenous knowledges and ways of knowing, and from the other eye with the strengths of mainstream knowledges and ways of knowing, and to use both these eyes together. This knowledge diversity accounts for a variety of perspectives on an issue and allows for more interconnected and innovative solutions that will be sustainable in the long run (Derr 2020).

\section{Seeking long-term solutions}

Strong evidence shows that classically, environmental solutions are based on problem-oriented research: assessing risks, establishing the risk parameters, and reducing risk (Zijp et al. 2016). Such approaches tend to focus on the short term and often involve regulatory approaches. However, short-term solutions ultimately do not solve complex long-term problems. To conclusively solve problems, adopting a solutions-focused mindset is key. Focusing on short-term timelines only creates band-aid solutions to wicked problems (Cone and Hayes 1980). This, in turn, creates feedback loops because environmental problems continually pull resources away from other issues. Seeking long-term, sustainable solutions has the potential to generate a relatively linear relationship between solutions and problems (i.e., as more long-term solutions are found, the number of problems will decrease; Kareiva and Fuller 2017). Furthermore, a solutions-based paradigm can look past rudimentary issues and target fundamental problems (Zijp et al. 2016). It is also important to recognize that most solutions will involve a political component, which influences timelines for progress given election cycles and bureaucratic inertia. Long-term political change may occur in the form of smaller (baby) steps that are important components of a long-term vision and plan (Rosenbaum 2016).

\section{Essential skills for problem solvers}

There are a series of essential skills for problem solvers (Fig. 1) that can be fostered to help achieve environmental solutions. These skills were identified through an iterative process of brainstorming and readings.

\section{Innovative thinking}

Innovative thinking during problem solving is what pushes the boundaries of the issues at hand (Isaksen et al. 2000). Innovative thinking is an inherent skill that everyone has access to and, with practice, can be developed. Recent work has conceptualized two distinct modes of innovative thinking: divergent, and convergent (CEF 2021). Divergent thinking involves generating a multitude of ideas through brainstorming and allows people to quickly move beyond the obvious ideas to find breakthrough ideas. Convergent thinking applies criteria to the brainstormed ideas so they can become actionable innovations. In essence, divergent thinking allows for the raw material to be pushed beyond everyday thinking, while convergent tools help screen, select, evaluate, and refine the ideas while retaining novelty and newness (CEF 2021).

\section{Critical thinking}

Critical thinking is essential in all aspects of problem solving. Lamont and Weidman (2020) explain that critical thinking works to limit bias and encourage an impartial viewpoint. Thinking critically about a problem creates a precise hypothesis that ensures solutions address the problem completely. Analytical thought is again required when evaluating the best outcome from all possible solutions. Pilgrim et al. (2019) bring to light the importance of evaluating credibility and resources when thinking critically 
Fig. 1. Essential skills of environmental problem solvers.

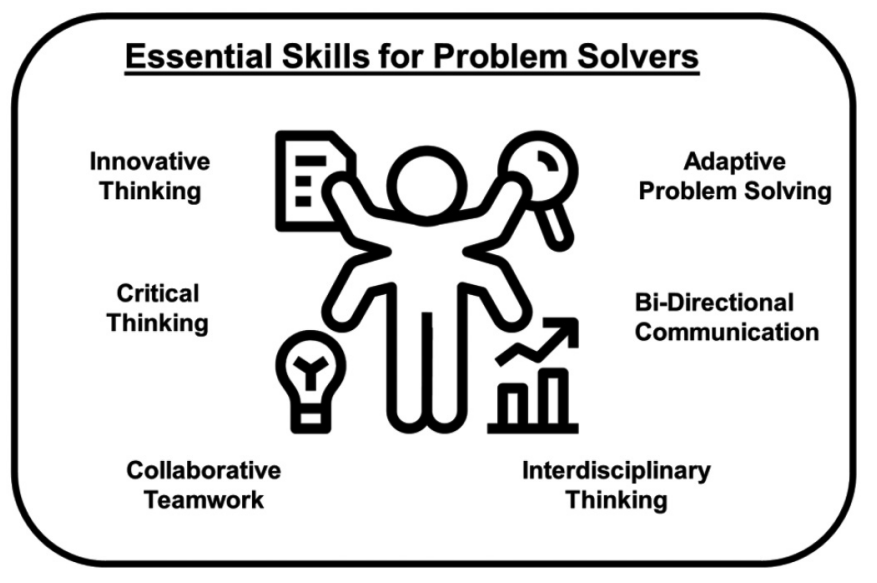

about solving a problem. Problem solving is not possible without some element of critical thinking, and is best when evident in all the phases of the process. Critical thinking can be enabled by using formal processes such as the aforementioned problem visualization and identification tools that allow problems to be broken down in a logical manner.

\section{Collaborative teamwork}

Recognizing they cannot do it alone, the contemporary problem solver needs to be able to engage in collaborative teamwork and collaborative learning toward a shared goal (e.g., solving an environmental problem). Brondizio et al. (2016) suggests that the concept of the Anthropocene acts as a bridge to connect individuals with different expertise and lived experiences. Collaborative teamwork is an approach that requires all involved to have a voice and be fully engaged in a way that capitalizes on the diversity of the team. At the core of effective collaborative teamwork is open communication and mutual respect. The idea of a collaborative approach to environmental problem solving is not new (see Selin and Chevez 1995) but is not always embraced or effective (usually because of team dynamics), thus emphasizing the need for training on how to both lead (having strong leadership is essential) and participate in such efforts in a respectful, meaningful, and productive way (Angelstam et al. 2013).

\section{Interdisciplinary thinking}

A key element of success in solving problems is the implementation of interdisciplinary thinking to approach problems from a variety of perspectives (Cadotte et al. 2017; Cooke et al. 2020b). This is particularly relevant for environmental problems, which are often complex because of their scales, connections across knowledge domains, and interdependencies with society and the economy (Dick et al. 2016). Individuals or teams that use an interdisciplinary approach that transcends disciplinary boundaries will draw from a variety of disciplines and integrate across diverse knowledge sources instead of taking a standard approach and viewing a problem in a traditional, one-dimensional (or disciplinary) manner (Clark et al. 2011). The evidence indicates that such collaborations enable problem solvers to address issues in a range of ways, while also being more equipped to adapt to changes that may arise because of the complexity of the problem solving team (Bodin 2017).

\section{Bidirectional communication}

Communication, and specifically communication with stakeholders and rightsholders, is an essential skill for problem solvers that is often overlooked. If all of the participants interested in an environmental issue communicate effectively to find a solution, this improves the chances of agreement and adherence to the
Fig. 2. Key elements of the mindset of environmental problem solvers.

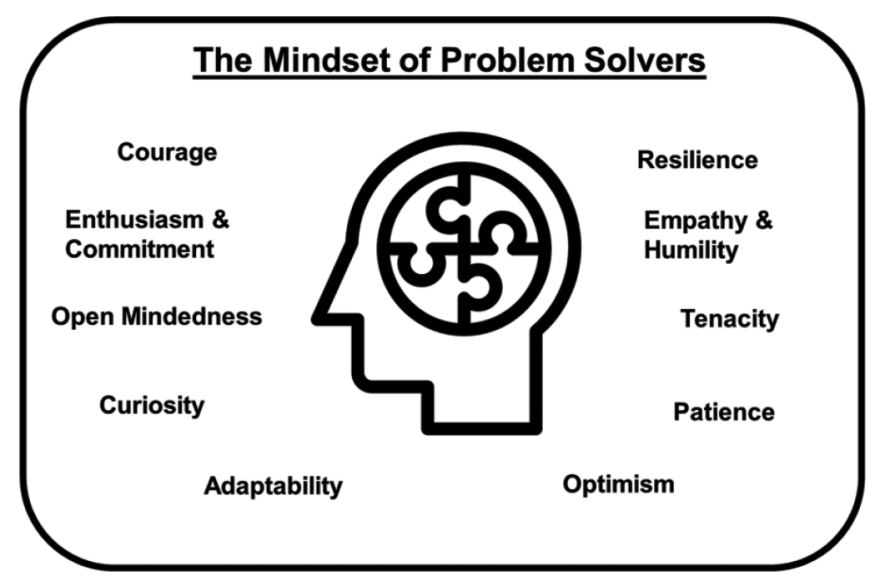

solution (Cox 2013; Zaval and Cornwell 2017). Communication should be a continuous, interactive dialogue to keep relevant parties up to date on the information that concerns them (Costanza and Jorgensen 2002). Effective communication increases the likelihood that knowledge (of various forms) will lead to action, and that participants feel included and heard during decision-making (Lindenfeld et al. 2012). Listening is also critical in communication because it ensures that all points of view are heard and acknowledged. Knowing your audience and having clear avenues of communication is a skill that allows a scientist to tailor how they present information based on the characteristics of their audience (Cooke et al. 2017).

\section{Adaptive problem solving}

Adaptability refers to the capacity to respond to change, uncertainty, and variability (Martin and Liem 2015). As our knowledge on environmental issues expands, our systems, policies, and values need to adapt. Adaptability can manifest as cognitive, behavioural, and (or) emotional adjustments (Martin and Liem 2015). When trying to create change, problem solvers must be flexible in all of these areas to overcome the challenges that they encounter, especially given the rapid rates at which scientific knowledge is increasing and society is changing (Scherer 2015). When problem solvers are able to adapt, more innovative solutions can be implemented.

\section{The mindset of problem solvers}

Here we share what we perceive to be elements of the mindset of problem solvers (Fig. 2) identified from collaborative brainstorming and our experiences. We acknowledge that there is a grey area between the concept of mindset (which is usually regarded as a way of thinking) and ethos (which is usually regarded as being about one's character) but for simplicity we use the term mindset to capture both concepts. Wei et al. (2020) used the word "disposition" but that implies a rather fixed state, whereas we believe that mindset development can be fostered and evolve. We preface this section noting that some level of pragmatism will help to minimize frustration. Yet, we also did not want to over-emphasize pragmatism, given that it has not served us well in environmental problem solving (Carolan 2020), at least at the level of the transformation and radical change needed to, for example, reverse the biodiversity crisis, restore degraded ecosystems, and address global climate change.

\section{Courage}

Taking on the enormous environmental challenges that lie before us requires courage. Fredericks (2014) argued that courage is an 
environmental virtue that should be fostered among environmental professionals and diverse publics; however, it is rarely discussed in the context of environmental problem solving. Some have suggested that courage might lead to risk-taking behaviour, but such risk can be mitigated with technical knowledge (Nielsen et al. 2009). That is to say, courage alone is insufficient to solve problems, but when combined with competencies, knowledge, and expertise, courage can be a powerful force (Nielsen et al. 2009), perhaps best embodied of late by Greta Thunberg (Kühne 2019). We are certainly at a stage in our history where courage will be needed and should be embraced by those working on environmental problems and solutions.

\section{Enthusiasm and commitment}

To be effective, problem solvers must be enthusiastic and committed to overcoming the challenge at hand (Bardwell 1991). Without enthusiasm, the problem solver may lack motivation and perseverance, especially for particularly challenging or wicked problems. Environmental problems are complex and typically have more than one pathway to a solution, which makes commitment essential for an environmental problem solver seeking the most feasible solution to the problem. Maintaining enthusiasm can be challenging but there is evidence that refocusing efforts on local or small (defined) problems can be effective (Ascher 2018). Fostering enthusiasm and commitment to problem solving for aspiring and practicing environmental actors should not be an inherently difficult task, given that most individuals who engage in such activities have a passion for the environment. The bigger challenge lies in maintaining enthusiasm and commitment in the face of the challenges, frustrations, and failures that are inevitable.

\section{Tenacity}

Environmental issues do not always have apparent or viable solutions, and the ability to power through these issues without losing hope is critical. The future of our planet's environment can seem bleak, which often requires overcoming feelings of insignificance or futility (Von der Porten and De Loë 2014). The tenacity to navigate through these discouraging emotions and focus on matters that can be addressed is critical in further progressing on environmental problems. Tenacity is also useful for overcoming other problems that can derail projects, such as challenges with partners or funding constraints. Furthermore, problems often do not have linear solutions, and problem solvers must view the problem from a variety of lenses over different stages in time (Treffinger et al. 2008). Tenacity provides the will to do so.

\section{Patience}

In the current age, with technological advancements and continuous space-time compression, society is accustomed to instant gratification. Therefore, it can prove frustrating to reconcile this fast-paced life with problem solving pathways that operate over longer timelines. Even beyond that, the problem solving processes themselves (i.e., improving public opinions, stakeholder engagement, acquiring permits and funding, building partnerships, etc.) can be challenging to manoeuvre. The recognition that problems may not be resolved instantaneously is vital. It need not be a pain point for problem solvers, but rather it should serve as a tool for building perseverance, motivation, and steadfastness (De Young 2011).

\section{Resilience}

Defined as the ability to adapt and recover from unpredictable adversity and challenges, resilience is particularly important during the process of solving wicked problems (Tainter and Taylor 2014). Finding solutions to complex environmental problems is rarely a linear process. Thus, resilience is required to overcome the many issues, challenges, and setbacks that can arise along the way.
Sappa and Barabasch (2020) suggest that resilience and creativity have a bidirectional relationship such that being resilient can increase one's creativity in finding solutions, while one's creativity can lead to greater resilience. Thus, resilience plays a large part in a problem solving mindset (Bardwell 1991). Resilience can be instilled in others by carefully framing environmental problems, as they are often framed as hopeless situations bound to provoke eco-anxiety rather than inspiration (Stanley et al. 2021). Stanley et al. (2021) reported that framing a problem to induce "eco-anger" is far more likely to inspire action than inducing "eco-anxiety" or "eco-depression."

\section{Open mindedness}

Finding environmental solutions requires receptiveness to new information, plans, or goals, and open-mindedness when weighing evidence during decision-making. The results from psychological research indicate that being open- or closed-minded is not constant, but varies with a person's goals and situation (Kruglanski and Boyatzi 2012; Riggs 2018). Ideological commitments and social and political values influence scientific research. When the interests and preferences of researchers allow bias in experimental design, data interpretation, or dissemination of results, the studies may not produce information that is accurate for solving a given problem (Wilholt 2009). It is critical that scientists engage in problem solving with an open mind so that they can overcome these various biases. Relatedly, fostering open-mindedness can be challenging and carries inherent risk if not combined with critical thinking when assessing diverse forms of evidence (Hare 1986).

\section{Empathy and humility}

Environmental scientists tend to think and act critically and analytically when problem solving; however, empathy and humility are required when proposing solutions to the public and understanding how environmental issues and solutions impact humans. A common issue levied against the scientific community is a supposed sense of superiority or detachment from the general public. Llorente et al. (2019) outline many of the disconnects between how environmental professionals (especially scientists) and the general public perceive each other. For example, environmental scientists commonly perceive climate change deniers to be particularly inferior due to the supposed arrogance of deniers. However, Ferkany (2015) argues that disparaging climate change deniers itself is a form of arrogance, and argues that displays of humility about one's knowledge creates a better path for connection with the public. The attitude that the scientific community is superior to or more intelligent than the general public alienates both sides, and detracts from efforts to solve environmental problems. Given the inherent connections between the environment and human wellbeing, it will be increasingly important for environmental solutions to be rooted in empathy, where those working on such solutions are both empathetic and demonstrate humility.

\section{Curiosity}

A key aspect in the mindset of problem solvers is curiosity (Mackay 2017). Solutions (whether elegant or not) usually begin as half-baked scraps of ideas that require time and reflection to grow. The source of all those idea scraps is curiosity. Curiosity engages people with problems, encouraging them to think deeply and rationally about potential solutions (Gino 2018). The benefits of tackling problems in this way are two-fold. First, curiosity is an innately human trait and moreover, is not a fixed value. Good leaders can rouse curiosity within people and inspire a whole group of problem solvers. Second, being curious does not unlock one or two potential solutions for a problem; infinite ideas can be flung against the proverbial problem wall until the best, worst, and all solutions in between have been explored. Problems require solutions. Solutions require ideas. Ideas are born from curiosity. 
Table 1. Potential strategies (formal training and informal) for fostering development of skills relevant to environmental problem solving.

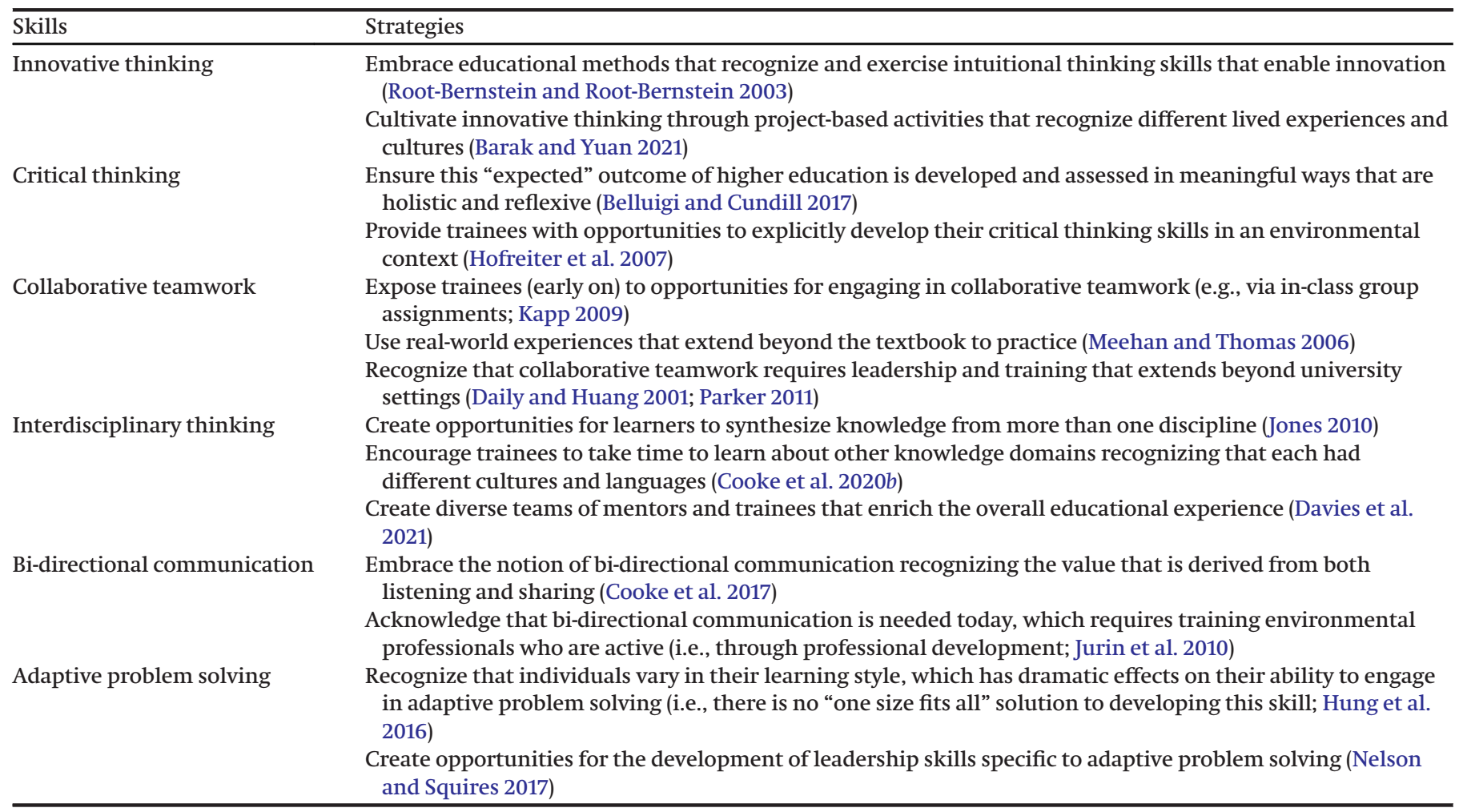

\section{Optimism}

According to Aspinwall et al. (2001), an optimist is a person with a positive outlook. If a person is not optimistic that a possible solution exists, they will likely lack the motivation required to analyze all relevant information and develop viable options. Believing that the problem has a solution is step one, but the problem solver must also see a benefit to finding that solution. Moreover, optimism is infectious in that it creates a motivational environment that encourages people to engage and cooperate on shared goals. In contrast to fear, which provokes a fight-or-flight response, those who are optimistic are likely to remain engaged in a goal and take action towards achieving it (McAfee et al. 2019). Also, optimistic individuals tend to maintain higher levels of psychological well-being, which makes them more likely to accept the reality of stressful and challenging situations (Cvitanovic and Hobday 2018). The concepts of hope and optimism are increasingly recognized as being important in both problem solvers and broader publics when it comes to dealing with environmental problems (Kelsey 2016), although we acknowledge that more work is needed to fully understand how hope and fear can be used most effectively to enable action (Kidd et al. 2019).

\section{Adaptability}

Learning mindsets can be categorized as either a growth mindset or a fixed mindset (Suh et al. 2011). In a growth mindset, it is thought that qualities are accumulated through one's efforts. In contrast, with a fixed mindset, qualities are rigid (Suh et al. 2011). Successful problem solvers should have a growth mindset that is characterized by adaptability. In a world that is continuously adapting and changing, the problems are changing as well. With the evolving world, there are continuous advancements in knowledge and technology so growth mindset individuals will continually think of ways to incorporate these advances into already achieved solutions. The best mindset to have is that there is no one best solution, but a solution that can continuously evolve (i.e., adaptive) and get better with time. Developing a mindset that allows one to be adaptable can be achieved by simple actions like stepping outside of one's comfort zone and learning from mistakes.

\section{Revising training to be solutions-oriented}

By reflecting on experiences in an environmental science program (the program where most of the authors are enrolled) and reviewing relevant literature, we identified a number of opportunities for revising or enhancing training programs to better ensure that graduates are poised to be environmental problem solvers. We recognize that every program is unique and that some of these ideas may already be operationalized in various locales. Moreover, this is not intended to be an exhaustive list. We preface this by noting that although it is possible to actually teach problem solving tools and methods (see Treffinger 1995; Hemming 2000), students need to be provided with opportunities to practice (and learn from failures) and develop aspects of the problem solving tool kit that we see as critical (see Table 1). Wei et al. (2020) emphasized the importance of ensuring that trainees obtain clarity about concepts and competencies needed to understand and tackle problems, and present an educational framework that describes what students should learn and how they should apply this knowledge to address complex socioenvironmental problems. This combination of theory and practice in developing problem solvers is logical and one we support and encourage. Underpinning such training opportunities is the need for good mentors and exposing learners to diverse individuals and cases where environmental problem solving has occurred.

In our deliberations it was clear that there was a need to ensure that all students (not just those in environmental programs) are aware of the interconnectedness of the environment with issues such as economics, social welfare, equity, food security, and so on. This could be accomplished with a mandatory environmental course for all students, no matter their program. Implementing such an initiative will require the support of academic leaders 
because it would require institutional buy-in and support. Students in environmental programs would benefit from more collaborative, project-oriented courses that include students from environmental science, environmental studies, environmental engineering, and other relevant disciplines (Cooke and Vermaire 2015). Given that most problem solving is done in a team environment, creating opportunities for trainees from different disciplines (outside of the aforementioned environmental programs) to learn with and from each other, and engage in collaborative teamwork, would potentially be of great benefit (e.g., Moslemi et al. 2009; Smith and McPherson 2020). This has the potential to lead to creative solutions that arise from multiple knowledge domains (Kulinski 2018). Rather than being given "fake" assignments and projects purely for didactic purposes, having learners work together on real problems has the potential to generate and implement real solutions (Steiner and Posch 2006). There was also interest in using problem solving rodeos (i.e., intense and focused team activities where there are attempts to understand and solve defined questions in a short period) outside of formal classroom training to develop ideas in an unconventional setting.

There was collective agreement in the need to be exposed to a diversity of topics during training, with inclusion of content such as leadership, economics, and behavioural science, given their important role in problem solving. Developing critical thinking skills can start early in education by engaging young people with complex problems and asking them to brainstorm solutions (Ampuero et al. 2015). With this approach, they will be less intimidated by the magnitude and controversial nature of environmental problems. Ample use of case studies and case histories to cover environmental successes and failures would be particularly useful. The undergraduate curriculum is only one aspect of training but is foundational in the development of environmental leaders.

\section{Conclusions}

Environmental solutions have been elusive. Given the urgency of most environmental problems and the intersection with human society, well-being, and economics (among many other issues and domains), there is a need to identify the recipe for achieving environmental solutions. We do not purport to have all the answers, but the ideas shared here represent what we believe are some of the key elements for success, as well as useful skills and aspects of the mindset needed to achieve them. What is novel is that these ideas were collated, debated, and summarized by learners in an undergraduate environmental science program while participating in a new course titled "Environmental Solutions". As others have candidly stated (see Jeanson et al. 2020), established environmental professionals and those currently in leadership roles have failed to generate the necessary solutions, so it will fall to the next generation to do so. It therefore follows that those individuals currently training to be environmental professionals are uniquely positioned to consider what it means to become an environmental problem solver. Such reflections will be directly relevant to those wishing to reframe how they approach environmental problems but also provide guidance for those who develop and deliver environmental training (see Wei et al. 2020 for a useful training framework). We recognize that there are other ideas beyond those shared here that can be salient to problem solving. Notably, luck and unanticipated events may be an important element of success. As such, following the ideas shared here cannot guarantee success. Nonetheless, the ideas shared here should contribute to ensuring that the next generation of learners have the ability to develop solutions that will work for the benefit of the environment, biodiversity, and humanity. As a group of learners poised to become the environmental problem solvers of tomorrow we are excited by what is possible if only provided with the opportunities to further refine our skills and shape our mind-set to be able to deliver on this challenge.

\section{Competing interests}

The authors declare that they are frustrated by the focus on identifying problems rather than solving them.

\section{Contributors' statement}

All of the authors contributed to all aspects of idea conception, writing, and editing.

\section{Funding statement}

Cooke is funded by the Natural Sciences and Engineering Research Council of Canada; Nyboer is funded by the Fonds de recherche Nature et technologies de Quebec.

\section{Acknowledgements}

This paper is a product of ENSC 4700 at Carleton University during the Winter 2021 semester delivered entirely online due to the COVID-19 pandemic. We are grateful to Elena Bennett, Abigail Lynch, Andy Danylchuk, Elliott Hazen, Heather Welch, Charles Krueger, and Stuart Orr for sharing their perspectives on environmental solutions. Two anonymous referees provided thoughtful comments on the manuscript.

\section{References}

Alexander, S.M., Provencher, J.F., Henri, D.A., Taylor, J.J., Lloren, J.I., Nanayakkara, L., et al. 2019. Bridging Indigenous and science-based knowledge in coastal and marine research, monitoring, and management in Canada. Environ. Evid. 8: 36. doi:10.1186/s13750-019-0181-3.

Ampuero, D., Miranda, C.E., Delgado, L.E., Goyen, S., and Weaver, S. 2015. Empathy and critical thinking: primary students solving local environmental problems through outdoor learning. J. Adv. Educ. Outdoor Learn, 15: 64-78. doi:10.1080/14729679.2013.848817.

Angelstam, P., Andersson, K., Annerstedt, M., Axelsson, R., Elbakidze, M., Garrido, P., et al. 2013. Solving problems in social-ecological systems: definition, practice and barriers of transdisciplinary research. AMBIO, 42: 254-265. doi:10.1007/s13280-012-0372-4. PMID:23475660.

Ascher, W. 2018. Safeguarding the enthusiasm for environmental studies: small is even more beautiful than before. J. Environ. Stud. Sci. 8: 104-109. doi:10.1007/s13412-017-0442-9.

Aspinwall, L.G., Ritcher, L., and Hoffman, R.R. 2001. Understanding how optimism works: An examination of optimists' adaptive moderation of belief and behaviour. In Optimism and pessimism: implications for theory, research and practice. Edited by E.C. Chang. American Psychological Association. pp. 217-238.

Barak, M., and Yuan, S. 2021. A cultural perspective to project-based learning and the cultivation of innovative thinking. Thinking Skills Creativity, 39: 100766. doi:10.1016/j.tsc.2020.100766.

Bardwell, L.V. 1991. Problem-framing: a perspective on environmental problem-solving. Environ. Manage. 15: 603-612. doi:10.1007/BF02589620.

Bardwell, L.V. 1994. Environmental problem solving: theory, practice and possibilities in environmental education. North American Association for Environmental Education, Troy, Ohio.

Bebbington, J., and Unerman, J. 2018. Achieving the United Nations sustainable development goals: an enabling role for accounting research. Account. Audit. Account. J. 31: 2-24. doi:10.1108/AAAJ-05-2017-2929.

Belluigi, D.Z., and Cundill, G. 2017. Establishing enabling conditions to develop critical thinking skills: a case of innovative curriculum design in Environmental Science. Environ. Edu. Res. 23(7): 950-971. doi:10.1080/13504622. 2015.1072802.

Bennett, E.M., Solan, M., Biggs, R., McPhearson, T., Norström, A.V., Olsson, P., et al. 2016. Bright spots: seeds of a good Anthropocene. Front. Ecol. Environ. 14: 441-448. doi:10.1002/fee.1309.

Blaint, P.J., Stewart, R.E., Desai, A., and Walters, L.C. (Editors). 2011. The challenge of wicked problems. In Wicked environmental problems: managing uncertainty and conflict. Island Press, Washington, D.C. pp. 1-6.

Bodin, O. 2017. Collaborative environmental governance: Achieving collective action in social-ecological systems. Science, 357(6352): eaan1114. doi:10.1126/ science.aan1114. PMID:28818915.

Boivin, N., and Crowther, A. 2021. Mobilizing the past to shape a better Anthropocene. Nat. Ecol. Evol. 5: 273-284. doi:10.1038/s41559-020-01361-4. PMID:33462488. 
Brondizio, E.S., O’Brien, K., Bai, X., Biermann, F., Steffen, W., Berkhout, F., et al. 2016. Re-conceptualizing the Anthropocene: A call for collaboration. Global Environ. Change, 39: 318-327. doi:10.1016/j.gloenvcha.2016.02.006.

Cadotte, M.W., Barlow, J., Nuñez, M.A., Pettorelli, N., and Stephens, P.A. 2017. Solving environmental problems in the Anthropocene: the need to bring novel theoretical advances into the applied ecology fold. J. Appl. Ecol. 54: 1-6. doi:10.1111/1365-2664.12855.

Carolan, M. 2020. Society and the environment: Pragmatic solutions to ecological issues. Routledge, New York.

Clark, S.G., Steen-Adams, M.M., Pfirman, S., and Wallace, R.L. 2011. Professional development of interdisciplinary environmental scholars. J. Environ. Stud. Sci. 1: 99-113. doi:10.1007/s13412-011-0018-z.

Cohen, B. 2007. Developing educational indicators that will guide students and institutions toward a sustainable future. New Direct. Inst. Res. 2007(134): 83-94. doi:10.1002/ir.215.

Cone, J.D., and Hayes, S.C. 1980. Environmental problems/behavioral solutions. Cambridge University Press.

Cooke, S.J. 2019. From frustration to fruition in applied conservation research and practice: ten revelations. Socio.-Ecol. Pract. Res. 1(1): 15-23. doi:10.1007/s42532-018-0002-x.

Cooke, S.J., and Vermaire, J.C. 2015. Environmental studies and environmental science today: inevitable mission creep and integration in action-oriented transdisciplinary areas of inquiry, training and practice. J. Environ. Stud. Sci. 5: 70-78. doi:10.1007/s13412-014-0220-x.

Cooke, S.J., Gallagher, A.J., Sopinka, N.M., Nguyen, V.M., Skubel, R.A., Hammerschlag, N., et al. 2017. Considerations for effective science communication. FACETS J. 2: 233-248. doi:10.1139/facets-2016-0055.

Cooke, S.J., Rytwinski, T., Taylor, J.J., Nyboer, E.A., Nguyen, V.M., Bennett, J.R., et al. 2020a. On "success" in applied environmental research-What is it, how can it be achieved, and how does one know when it has been achieved? Environ. Rev. 28(4): 357-372. doi:10.1139/er-2020-0045.

Cooke, S.J., Nguyen, V.M., Anastakis, D., Scott, S.D., Turetsky, M.R., Amirfazli, A., et al. 2020b. Diverse perspectives on interdisciplinarity from the Members of the College of The Royal Society of Canada. FACETS J. 5: 138-165. doi:10.1139/facets-2019-0044.

Costanza, R., and Jorgensen, S.E. 2002. Understanding and solving environmental problems in the 21st century: toward a new, integrated hard problem science. Elsevier, New York.

Cox, R. 2013. Environmental communication and the public sphere. Sage, New York.

Creative Education Foundation (CEF). 2021. What is creative problem solving? Available from https://www.creativeeducationfoundation.org/whatis-cps/.

Crutzen, P.J. 2006. The "Anthropocene". In Earth system science in the Anthropocene. Springer, Berlin, Heidelberg. pp. 13-18. doi:10.1007/3-54026590-2_3.

Cvitanovic, C., and Hobday, A.J. 2018. Building optimism at the environmental science-policy-practice interface through the study of bright spots. Nat. Commun. 9: 3466. doi:10.1038/s41467-018-05977-w. PMID:30154434.

Daily, B.F., and Huang, S.C. 2001. Achieving sustainability through attention to human resource factors in environmental management. Int. J. Op. Prod. Manage. 21: 1539-1552. doi:10.1108/01443570110410892.

Dalby, S. 2016. Framing the Anthropocene: The good, the bad and the ugly. Anthropocene Rev. 3: 33-51. doi:10.1177/2053019615618681.

Davies, S., Putnam, H., Ainsworth, T., Baum, J., Bove, C., Crosby, S., et al. 2021. Shifting our value system beyond citations for a more equitable future. PLoS Biol. [In press.]

Derr, V. 2020. Diverse perspectives on action for positive social and environmental change. Environ. Educ. Res. 26: 219-237. doi:10.1080/13504622.2020.1715925.

De Young, R. 2011. Slow wins: patience, perseverance and behaviour change. Carbon Manage. 2: 607-611. doi:10.4155/cmt.11.59.

Dick, M., Rous, A.M., Nguyen, V.M., and Cooke, S.J. 2016. Necessary but challenging: multiple disciplinary approaches to solving conservation problems. FACETS J. 1: 67-82. doi:10.1139/facets-2016-0003.

Elmqvist, T., Andersson, E., Frantzeskaki, N., McPhearson, T., Olsson, P., Gaffney, O., et al. 2019. Sustainability and resilience for transformation in the urban century. Nat. Sustain. 2: 267-273. doi:10.1038/s41893-019-0250-1.

Evans, M.C., and Cvitanovic, C. 2018. An introduction to achieving policy impact for early career researchers. Palgrave Commun. 4(1): 88. doi:10.1057| s41599-018-0144-2.

Ewel, K.C. 2001. Natural resource management: The need for interdisciplinary collaboration. Ecosystems, 4: 716-722. doi:10.1007/s10021-001-0040-1.

Ferkany, M. 2015. Is it arrogant to deny climate change or is it arrogant to say it is arrogant? Understanding arrogance and cultivating humility in climate change discourse and education. Environ. Values, 24: 705-724. doi:10.3197/096327115X14420732702572.

Ford, A.T., Ali, A.H., Colla, S.R., Cooke, S.J., Lamb, C.T., Pittman, J., et al. 2021. Understanding and avoiding misplaced efforts in conservation. FACETS J. 6(1): 252-271. doi:10.1139/facets-2020-0058.

Fredericks, R. 2014. Courage as an environmental virtue. Environ. Ethics, 36: 339-355. doi:10.5840/enviroethics201436334.

Gardner, G.T., and Stern, P.C. 1996. Environmental problems and human behavior. Allyn \& Bacon, U.K.
Gino, F., 2018. The business case for curiosity. Harvard Business Review. [September 2018 issue.] pp. 48-57. Available from https://hbr.org/2018/09/ the-business-case-for-curiosity [accessed 3 March 2021].

Hare, W. 1986. Fostering open-mindedness in education. High School J. 69(3): 183-189.

Hayes, J. 2018. The theory and practice of change management. 5th ed. Palgrave Macmillan, London.

Hemming, H.E. 2000. Encouraging critical thinking "But... what does that mean?" McGill J. Educ. 35: 173-186.

Hofreiter, T.D., Monroe, M.C., and Stein, T.V. 2007. Teaching and evaluating critical thinking in an environmental context. Appl. Environ. Educ. Commun. 6(2): 149-157. doi:10.1080/15330150701598197.

Huesemann, M.H. 2001. Can pollution problems be effectively solved by environmental science and technology? An analysis of critical limitations. Ecol. Econ. 37: 271-287. doi:10.1016/S0921-8009(00)00283-4.

Hung, Y.H., Chang, R.I., and Lin, C.F. 2016. Hybrid learning style identification and developing adaptive problem-solving learning activities. Comput. Hum. Behav. 55: 552-561. doi:10.1016/j.chb.2015.07.004.

Isaksen, S., Dorval, B., and Treffinger, D. 2000. Creative approaches to problem solving: a framework for change. 2nd. ed. Creative Problem Solving Group-Buffalo, Williamsville, New York.

Jeanson, A.L., Soroye, P., Kadykalo, A.N., Ward, T.D., Paquette, E., Abrams, A.E., et al. 2020. Twenty actions for a "good Anthropocene"-perspectives from early-career conservation professionals. Environ. Rev. 28(1): 99-108. doi:10.1139/ er-2019-0021.

Johnston, R.J. 1989. Environmental problems: nature, economy and state. Belhaven Press (Pinter), UK.

Jones, C. 2010. Interdisciplinary approach-advantages, disadvantages, and the future benefits of interdisciplinary studies. ESSAI, 7(1): 26.

Jurin, R.R., Roush, D., and Danter, K.J. 2010. Environmental communication.: skills and principles for natural resource managers, scientists, and engineers. Springer Science \& Business Media, UK.

Kapp, E. 2009. Improving student teamwork in a collaborative project-based course. College Teaching, 57(3): 139-143. doi:10.3200/CTCH.57.3.139-143.

Kareiva, P., and Fuller, E. 2017. The long and short of environmental solutions. Global Pol. 8: 257-258. doi:10.1111/1758-5899.12414.

Kelly, R., Mackay, M., Nash, K.L., Cvitanovic, C., Allison, E.H., Armitage, D., et al. 2019. Ten tips for developing interdisciplinary socio-ecological researchers. Socio.-Ecol. Pract. Res. 1: 149-161. doi:10.1007/s42532-019-00018-2.

Kelsey, E. 2016. Propagating collective hope in the midst of environmental doom and gloom. Can. J. Environ. Educ. 21: 23-40.

Kidd, L.R., Bekessy, S.A., and Garrard, G.E. 2019. Neither hope nor fear: empirical evidence should drive biodiversity conservation strategies. Trends Ecol. Evol. 34: 278-282. doi:10.1016/j.tree.2019.01.018.

Kinzig, A.P., Ehrlich, P.R., Alston, L.J., Arrow, K., Barrett, S., Buchman, T.G., et al. 2013. Social norms and global environmental challenges: the complex interaction of behaviors, values, and policy. BioScience, 63: 164-175. doi:10.1525/bio.2013.63.3.5. PMID:25143635.

Klimoski, R.J., and Karol, B.L. 1976. The impact of trust on creative problem solving groups. J. Appl. Psychol. 61: 630-633. doi:10.1037/0021-9010.61.5.630.

Kruglanski, A.W., and Boyatzi, L.M. 2012. The psychology of closed and open mindedness, rationality, and democracy. Crit. Rev. 24: 217-232. doi:10.1080/ 08913811.2012.711023.

Krumholz, J., Barber, T., and Jadot, C. 2010. Avoiding "Band-Aid" solutions in ecosystem restorations. Ecol. Restor. 28: 17-19. doi:10.3368/er.28.1.17.

Kühne, R.W. 2019. Climate change: the science behind Greta Thunberg and Fridays for future. OSF Preprints. September 2 [In press]. doi:10.31219/osf. io/2n6kj.

Kulinski, A.R. 2018. Awakening the creative problem solver. Art Educ. 71: 42-47. doi:10.1080/00043125.2018.1482165.

Lamont, P., and Weidman, N. 2020. The construction of "critical thinking": Between how we think and what we believe. Hist. Psychol. 23: 232-251. doi:10.1037/hop0000145. PMID:32191060.

Lewis, S.L., and Maslin, M.A. 2015. Defining the anthropocene. Nature, 519(7542): 171-180. doi:10.1038/nature14258. PMID:25762280.

Lim, M., Lynch, A.J., Fernández-Llamazares, Á., Balint, L., Basher, Z., Chan, I., et al. 2017. Early-career experts essential for planetary sustainability. Curr. Opin. Environ. Sust. 29: 151-157. doi:10.1016/j.cosust.2018.02.004.

Lindenfeld, L.A., Hall, D.M., McGreavy, B., Silka, L., and Hart, D. 2012. Creating a place for environmental communication research in sustainability science. Environ. Commun. 6: 23-43. doi:10.1080/17524032.2011.640702.

Llorente, C., Revuelta, G., Carrio, M., and Porta, M. 2019. Scientists opinions and attitudes towards citizens' understanding of science and their role in public engagement activities. PLoS ONE, 14: e0224262. doi:10.1371/journal.pone. 0224262. PMID:31721768.

Mackay, H. 2017. Curiosity is essential to problem solving. The Business Journals. Bizjournals.com. Available from https://www.bizjournals.com/bizjournals/howto/growth-strategies/2017/11/curiosity-is-essential-to-problem-solving.html [accessed 3 March 2021].

Martin, A., and Liem, G.A.D. 2015. The role of adaptability in tackling climate and environmental challenges. Geog. Educ. 28: 15-17.

McAfee, D., Doubleday, Z.A., Geiger, N., and Connell, S.D. 2019. Everyone loves a success story: Optimism inspires conservation engagement. BioScience, 69: 274-281. doi:10.1093/biosci/biz019. 
Meehan, B., and Thomas, I. 2006. Teamwork: Education for entrants to the environment professions. Environ. Educ. Res. 12(5): 609-623. doi:10.1080/ 13504620601053571.

Meppem, T., and Bourke, S. 1999. Different ways of knowing: a communicative turn toward sustainability. Ecol. Econ. 30: 389-404. doi:10.1016/S09218009(99)00053-1.

Miller, A. 1999. Environmental problem solving: psychosocial barriers to adaptive change. Springer Science \& Business Media.

Moody, D.L. 2005. Theoretical and practical issues in evaluating the quality of conceptual models: current state and future directions. Data Knowl. Eng. 55: 243-276. doi:10.1016/j.datak.2004.12.005

Moslemi, J.M., Capps, K.A., Johnson, M.S., Maul, J., McIntyre, P.B., Melvin, A.M., et al. 2009. Training tomorrow's environmental problem solvers: an integrative approach to graduate education. BioScience, 59: 514-521. doi:10.1525/bio. 2009.59.6.10

Nelson, T., and Squires, V. 2017. Addressing complex challenges through adaptive leadership: a promising approach to collaborative problem solving. JOLE, 16(4): 111-123. doi:10.12806/V16/I4/T2.

Nielsen, S.B., Hoffmann, B., Quitzau, M.B., and Elle, M. 2009. Mobilizing the courage to implement sustainable design solutions: Danish experiences. Archit. Eng. Des. Manage. 5: 53-61. doi:10.3763/aedm.2009.0906.

Osbaldiston, R., and Schott, J.P. 2012. Environmental sustainability and behavioral science: meta-analysis of proenvironmental behavior experiments. Environ. Behav. 44: 257-299. doi:10.1177/0013916511402673.

Parker, G.M. 2011. Team players and teamwork: new strategies for developing successful collaboration. John Wiley \& Sons, New York.

Pereira, L., Bennett, E., Biggs, R., Mangnus, A., Norstrom, A.V., Peterson, G., et al. 2019. Seeding change by visioning good Anthropocenes. Solutions J. 10(3). Available from https://thesolutionsjournal.com/2019/08/19/seedingchange-visioning-good-anthropocenes/.

Pilgrim, J., Vasinda, J., Bledsoe, C., and Martinez, E. 2019. Critical thinking is critical: octopuses, online sources, and reliability reasoning. Read. Teach. 73: 85-93. doi:10.1002/trtr.1800.

Proulx, G. 2004. Integrating scientific method \& critical thinking in classroom debates on environmental issues. Am. Biol. Teach. 66(1): 26-33. doi:10.2307| 4451613.

Raudsepp-Hearne, C., and Peterson, G.D. 2016. Scale and ecosystem services: How do observation, management, and analysis shift with scale - lessons from Quebec. Ecol. Soc. 21: 13. doi:10.5751/ES-08605-210316.

Reid, A.J., Brooks, J.L., Dolgova, L., Laurich, B., Sullivan, B.G., Szekeres, P., et al. 2017. Post-2015 Sustainable Development Goals still neglecting their environmental roots in the Anthropocene. Environ. Sci. Pol. 77: 179-184. doi:10.1016/j.envsci.2017.07.006.

Reid, A.J., Eckert, L.E., Lane, J.F., Young, N., Hinch, S.G., Darimont, C.T., et al. 2021. Two-eyed seeing": an Indigenous framework to transform fisheries research and management. Fish Fish, 22(2): 243-261. doi:10.1111/faf.12516.

Reyers, B., Stafford-Smith, M., Erb, K.H., Scholes, R.J., and Selomane, O. 2017. Essential variables help to focus sustainable development goals monitoring. Curr. Opin. Environ. Sustain. 26: 97-105. doi:10.1016/j.cosust.2017.05.003.

Riggs, W. 2018. Open-mindedness. In The Routledge handbook of virtue epistemology. Routledge, New York. pp. 141-154.

Robinson, B.H. 2009. E-Waste: An assessment of global production and environmental impacts. Sci. Total Environ. 408: 183-191. doi:10.1016/j.scitotenv.2009. 09.044. PMID:19846207.

Root-Bernstein, R., and Root-Bernstein, M. 2003. Intuitive tools for innovative thinking. In The international handbook on innovation. Elsevier, U.K. pp. 377-387.

Rosenbaum, W.A. 2016. Environmental politics and policy. CQ Press, Washington, D.C.

Sappa, V., and Barabasch, A. 2020. Forum-theatre technique and active problem solving: A resilience-building intervention among in-service teachers. J. Adult Continuing Educ. 26: 43-60. doi:10.1177/1477971419842884.

Scherer, R. 2015. Is it time for a new measurement approach? A closer look at the assessment of cognitive adaptability in complex problem solving. Front. Psychol. 6: 1664. doi:10.3389/fpsyg.2015.01664. PMID:26579045.

Schnurr, R.E., Alboiu, V., Chaudhary, M., Corbett, R.A., Quanz, M.E., Sankar, K., et al. 2018. Reducing marine pollution from single-use plastics (SUPs): a review. Mar. Pollut. Bull. 137: 157-171. doi:10.1016/j.marpolbul. 2018.10.001. PMID:30503422.

Selin, S., and Chevez, D. 1995. Developing a collaborative model for environmental planning and management. Environ. Manage. 19: 189-195. doi:10.1007/ BF02471990.

Sloman, S. 2005. Causal models: How people think about the world and its alternatives. Oxford University Press, U.K.
Smith, J.G., and McPherson, M.L. 2020. A cross-campus professional development program strengthens graduate student leadership in environmental problem-solving. Elementa, 8: 85. doi:10.1525/elementa.085.

Stanley, S.K., Hogg, T.L., Leviston, Z., and Walker, I. 2021. From anger to action: Differential impacts of eco-anxiety, eco-depression, and eco-anger on climate action and wellbeing. J. Clim. Change Health, 1: 100003. doi:10.1016/j. joclim.2021.100003.

Steffen, W., Persson, Å., Deutsch, L., Zalasiewicz, J., Williams, M., Richardson, K., et al. 2011. The Anthropocene: from global change to planetary stewardship. AMBIO, 40: 739-761. doi:10.1007/s13280-011-0185-x. PMID:22338713.

Steiner, G., and Posch, A. 2006. Higher education for sustainability by means of transdisciplinary case studies: An innovative approach for solving complex, real-world problems. J. Cleaner Prod. 14: 877-890. doi:10.1016/j.jclepro. 2005.11.054.

Stevens, C., and Kanie, N. 2016. The transformative potential of the Sustainable Development Goals (SDGs). Int. Environ. Agreements, 16: 393-396. doi:10.1007/s10784-016-9324-y.

Suh, J., Graham, S., Ferranone, T., Kopeinig, G., and Bertholet, B. 2011. Developing persistent and flexible problem solvers with a growth mindset. In Motivation and disposition: pathways to learning mathematics. National Council of Teachers of Mathematics. pp. 169-184.

Tainter, J.A., and Taylor, T.G. 2014. Complexity, problem-solving, sustainability, and resilience. Build. Res. Inf. 42: 168-181. doi:10.1080/09613218. 2014.850599.

Tawfik, A., and Jonassen, D. 2013. The effects of successful versus failurebased cases on argumentation while solving decision-making problems. Educ. Tech. Res. Dev. 61: 385-406. doi:10.1007/s11423-013-9294-5.

Toll, J.E. 1999. Elements of environmental problem-solving. Hum. Ecol. Risk Assess. 5: 275-280. doi:10.1080/10807039991289428.

Treffinger, D.J. 1995. Creative problem solving: overview and educational implications. Educ. Psychol. Rev. 7: 301-312. doi:10.1007/BF02213375.

Treffinger, D.J., Selby, E.C., and Isaksen, S.G. 2008. Understanding individual problem-solving style: a key to learning and applying creative problem solving. Learn. Individual Differences, 18: 390-401. doi:10.1016/j.lindif. 2007.11.007.

Trudgill, S.T. 1990. Barriers to a better environment: What stops us solving environmental problems? Belhaven Press, U.K.

Tsuji, L.J., and Ho, E. 2002. Traditional environmental knowledge and western science: in search of common ground. Can. J. Native Stud. 22: 327-360.

Tukker, A., Charter, M., Vezzoli, C., Stø, E., and Andersen, M.M. 2017. System Innovation for sustainability 1: Perspectives on radical changes to sustainable consumption and production. Routledge, New York.

Vallero, D.A. 2006. Lessons learned: a case approach to environmental problems. Paradigms Lost, pp. 13-54. Elsevier, U.K.

Van den Bergh, J.C. 2013. Environmental and climate innovation: Limitations, policies and prices. Technol. Forecast. Social Change, 80: 11-23. doi:10.1016/j.techfore.2012.08.004

Vitousek, P.M., Mooney, H.A., Lubchenco, J., and Melillo, J.M. 1997. Human domination of Earth's ecosystems. Science, 277(5325): 494-499. doi:10.1126| science.277.5325.494.

Von der Porten, S., and De Loë, R.C. 2014. How collaborative approaches to environmental problem solving view Indigenous peoples: a systematic review. Soc. Nat. Res. 27: 1040-1056. doi:10.1080/08941920.2014.918232.

Washington, H. 2015. Demystifying sustainability: towards real solutions. Routledge, New York.

Wei, C.A., Deaton, M.L., Shume, T.J., Berardo, R., and Burnside, W.R. 2020. A framework for teaching socio-environmental problem-solving. J. Environ. Stud. Sci. 10: 467-477. doi:10.1007/s13412-020-00603-y.

Wilholt, T. 2009. Bias and values in scientific research. Stud. Hist. Philos. Sci. Part A, 40: 92-101. doi:10.1016/j.shpsa.2008.12.005.

Young, O.R., and Stokke, O.S. 2020. Why is it hard to solve environmental problems? The perils of institutional reductionism and institutional overload. Int. Environ. Agreements, 20: 5-19. doi:10.1007/s10784-020-09468-6.

Zaval, L., and Cornwell, J.F. 2017. Effective education and communication strategies to promote environmental engagement. Eur. J. Educ. 52(4): 477-486. doi:10.1111/ejed.12252.

Zedler, J.B. 2007. Success: an unclear, subjective descriptor of restoration outcomes. Ecol. Restor. 25(3): 162-168. doi:10.3368/er.25.3.162.

Zijp, M.C., Posthuma, L., Wintersen, A., Devilee, J., and Swartjes, F.A. 2016. Definition and use of solution-focused sustainability assessment: a novel approach to generate, explore and decide on sustainable solutions for wicked problems. Environ. Int. 91: 319-331. doi:10.1016/j.envint.2016.03. 006 . 